\title{
Apolipoprotein $E$ gene polymorphism influenced glycemic status among Malaysians
}

\author{
K. M. Hafizur Rahman ${ }^{1,2,{ }^{*}, \text { Md. Sanower Hossain }}{ }^{3,4}$, Nazmul Haque ${ }^{5}$, Tariq Bin Abdul Razak ${ }^{6}$, Hussain Ahmad ${ }^{2}$
}

${ }^{1}$ Department of Basic Medical Sciences, Kulliyyah of Pharmacy, International Islamic University, 25200 Kuantan, Pahang, Malaysia

${ }^{2}$ Department of Pharmacology and Therapeutics, Sylhet Women's Medical College, Sylhet, Bangladesh

${ }^{3}$ Department of Biomedical Sciences, Kulliyyah of Allied Health Sciences, International Islamic University Malaysia, 25200 Kuantan, Pahang, Malaysia

${ }^{4}$ Department of Biological Sciences, Faculty of Science, Sristy College of Tangail, 1900 Tangail, Bangladesh

${ }^{5}$ Department of Oral Biology and Biomedical Sciences, Faculty of Dentistry, MAHSA University, Selangor, Malaysia

${ }^{6}$ Kulliyyah of Medicine, International Islamic University, 25200 Kuantan, Pahang, Malaysia

\section{Correspondence}

K. M. Hafizur Rahman, Department of Basic Medical Sciences, Kulliyyah of Pharmacy, International Islamic University, 25200 Kuantan, Pahang, Malaysia

Department of Pharmacology and Therapeutics, Sylhet Women's Medical College, Sylhet, Bangladesh

Email: dr.hafizur@yahoo.com

\section{History}

- Received: Apr 26, 2019

- Accepted: Jun 08, 2019

- Published: Jul 15, 2019

\section{DOI :}

https://doi.org/10.15419/bmrat.v6i7.557

\section{Check for updates}

\section{Copyright}

( ) Biomedpress. This is an openaccess article distributed under the terms of the Creative Commons Attribution 4.0 International license.

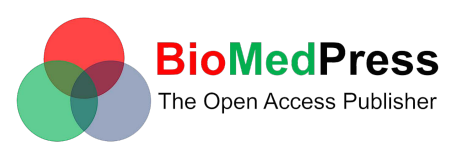

\begin{abstract}
Aim: In the last decade Apolipoprotein E (APOE) gene polymorphism has been identified as one of the risk factors of type 2 diabetes mellitus (T2DM). Though more than $11 \%$ population of Malaysia are suffering from T2DM, there is inadequate data on the correlation between the APOE gene polymorphism and pathogenesis of diabetes among Malaysians. Hence, in this study we aimed to find out the association between the frequencies of APOE allele and fasting blood glucose (FBG) concentration among subjects with T2DM. Methods: A total of 102 subjects were recruited into two distinct groups, 51 in diabetes (cases) and 51 in non-diabetes (control) group. Their fasting blood sample was tested for FBG, while APOE genotyping was carried out using restriction fragment length polymorphism technique. Predictive Analytics Software (PASW) statistics, version 18.0, was used for statistical analyses. Results: There was no association between APOE alleles and T2DM; odd ratios for the e2, e3 and e4 alleles were 1.51 (95\%Cl: 0.615-3.706), 0.77 (95\%Cl: 0.431-1.375) and 1.12 (95\%Cl: 0.584-2.131) respectively. The highest mean FBG was found in subjects with e2 alleles, followed by e4 and e3 alleles in both cases and control groups. Both e2 and e4 alleles were significantly linked to higher mean FBG ( $p=0.03$ and 0.04 for the respectively) compared to e3 allele in diabetes group. Conclusions: Although the APOE gene was not found to be associated with T2DM, it may influence glycemic status among subjects.
\end{abstract}

Key words: $A P O E, F B G$, polymorphism, T2DM

\section{INTRODUCTION}

Diabetes is a chronic metabolic disease that affects $9 \%$ of adults all around the world ${ }^{1}$. It is one of the major causes of morbidity and mortality among adults. In Malaysia, as per National Health and Morbidity Survey report 2015, prevalence of diabetes among adults of age 18 years and above is $17.5 \%{ }^{2}$. While World Health Organization (WHO), in the 'Global Status Report on Noncommunicable Diseases 2014', reported that the prevalence of diabetes among Malaysian adults is $11.1 \%$, which is 1.2 times higher than the global prevalence ${ }^{1}$.

From the genetic point of view, the causes of diabetes can be divided into monogenic and polygenic disease. Usually, the monogenic defects cause type 1 diabetes mellitus (T1DM) by affecting the production of insulin from beta cells of pancreas, and it contributes to $1-5 \%$ cases of all diabetes ${ }^{3}$. On the other hand, type 2 diabetes mellitus (T2DM) that contributes 90-95\% of all diabetes, is a chronic multifactorial disease of adulthood $^{3,4}$. T2DM results from a complex interactions between multiple genetic and environmental factors, where pre-existing susceptible genes are being triggered by nongenetic environmental factors, such as consumption of junk food, decreased opportunity and motivation for physical activity, and awareness among the genetically susceptible individuals ${ }^{5,6}$.

About a decade ago, the apolipoprotein E (APOE) gene was suggested as a susceptible gene that could induce pathogenesis of $\mathrm{T}_{2} \mathrm{DM}^{7}$. Apolipoprotein $\mathrm{E}$ (apoE) is a small glycoprotein ${ }^{8}$ with the molecular weight of $34 \mathrm{kDa}^{9}$, and is mainly secreted from the liver ${ }^{10}$. The primary role of circulating apoE is to facilitate the interaction of chylomicron remnants and intermediate density lipoproteins (IDL) with lipoprotein receptors, namely the low-density lipoprotein (LDL) receptors (LDLr), and the chylomicron remnants or apoE receptors ${ }^{10,11}$. It also promotes the efficient uptake of these lipoproteins from the circulation and takes part in cellular cholesterol efflux and reverse cholesterol transportation ${ }^{12}$. Concentration of plasma apoE and its binding capability is regulated by the $A P O E$ gene, which is located in the long arm of chromosome 19 , more precisely at $19 \mathrm{q} 13.2^{13}$. APOE gene possesses three alleles, namely e2, e3 and $\mathrm{e}$, which are responsible for the production of corresponding E2, E3 and E4 plasma isoproteins ${ }^{7}$. The $A P O E$ gene is polymorphic in nature with having six genotypes, three of which are homozygous (e2/e2, e3/e3 and e4/e4) and three are heterozygous (e2/e3, 
$\mathrm{e} 2 / \mathrm{e} 4$ and e3/e4) ${ }^{14}$. Variations in the plasma apoE are due to cysteine-arginine interchanges in the chemical structure. ApoE3 contains a cysteine residue at 112 and an arginine residue at 158 , while apoE2 contains cysteine residues at the both positions, and apoE4 contains arginine residue at the both positions ${ }^{11,15}$. Corresponding single nucleotide polymorphisms at the genetic level is involved in the modification of amino acid sequences at the protein level ${ }^{16}$.

Several studies on the role of APOE gene in developing pathological conditions of diabetes have been conducted and the pathogenesis was further linked to lipid and lipoprotein metabolic abnormalities ${ }^{17-21}$. However, there are scarcity of similar studies on Malaysian populations. Hence, in this study we aimed to evaluate the relationship between APOE gene polymorphism and T2DM among Malaysian subjects.

\section{METHODS}

\section{Ethical approval}

The declaration of Helsinki was strictly followed in this study. Ethical approval (Ref. IIUM/305/20/4/10) was obtained from the International Islamic University (IIUM) Ethics Committee. Moreover, signed informed written consent was also collected from the participants prior to blood collection.

\section{Sample selection}

A total of 102 study subjects were recruited in this case-control study. 51 subjects with uncontrolled T2DM were enrolled as case and 51 subjects without T2DM were enrolled as control. Only Malaysian subjects aged 40 years or above were recruited. The groups were matched for age ( \pm 10 years) and ethnicity. Any ongoing treatments or medications of the study subjects were not stopped for this research.

\section{Collection of blood}

After an initial interview, fasting (at least 8 hours, overnight) blood samples were collected into two vacutainers. Plasma was separated from blood shortly after collection and stored at $-80^{\circ} \mathrm{C}$ until further analysis. Ethylenediaminetetraacetic acid (EDTA) vacutainers containing whole blood sample were also stored at the same temperature for genotyping.

\section{Fasting blood glucose analysis}

The fasting blood glucose concentration was measured according to the glucose oxidase method using Bayer Express Plus Chemistry Analyzer (model: 550, Bayer Diagnostic, Siemens, USA). The standard laboratory protocol for the machine was followed.
Apolipoprotein E gene polymorphism analysis

Genomic DNA was extracted from $200 \mathrm{ml}$ of human whole blood using Invisorb Spin Blood Mini Kit (Stratec Molecular Gmbh, Germany) following the manufacturer's protocol. Three common alleles of the APOE gene were amplified by polymerase chain reaction (PCR) using TopTaq Master Mix Kit (QIAGEN, Germany). The final reaction volume was 25 ml for each sample, which consisted of 1.25 units TopTaq DNA polymerase, 1x PCR buffer solution, $3 \mathrm{mM}$ $\mathrm{MgCl}_{2}$ and $200 \mathrm{mM}$ of each dNTP and $5 \mathrm{ml}$ of the genomic DNA. Concentration of each primer (forward: 5'-TAA GCT TGG CAC GGC TGT CCA AGG A3' and reverse: 5'-ACA GAA TTG GCC CCG GCC TGG TAC AC-3'; Invitrogen, USA) in the final reaction volume was $0.5 \mathrm{mM}$. Molecular grade glycerol (10\% in each final reaction volume) was used due to high melting temperature of the selected primers. The PCR operation conditions included initial denaturation phase at $95^{\circ} \mathrm{C}$ for 5 minutes, followed by $30 \mathrm{cy}$ cles of denaturation at $95^{\circ} \mathrm{C}$ for 30 seconds, annealing at $60^{\circ} \mathrm{C}$ for 20 seconds, extension phase at $72^{\circ} \mathrm{C}$ for 20 seconds, and the final elongation at $72^{\circ} \mathrm{C}$ for $10 \mathrm{~min}$ utes. Amplification was confirmed by $1 \%$ agarose gel electrophoresis stained with ethidium bromide. After confirmation of amplification, $10 \mathrm{ml}$ of each amplified DNA was then digested at $37^{\circ} \mathrm{C}$ for an hour by HhaI restriction enzyme (Invitrogen, USA). The digested products were then visualized in $4 \%$ agarose gel stained with ethidium bromide. A single band of about 244 base pairs (bp) in 1\% agarose gel was considered confirmatory to the amplification (Figure 1). Seven bands at different levels were identified in $4 \%$ agarose gel after the digestion, the first four bands were used to identify different $A P O E$ genotypes based on their presence/absence at the identical bp levels (Figure 1). The presence of the first two bands (at 94 and $81 \mathrm{bp}$ ) was used to identify the e2/e2 genotype, first two and fourth bands (at 94, 81 and $66 \mathrm{bp}$ ) represented e2/e3 genotype, all four bands (at 94, 81, 66 and $58 \mathrm{bp}$ ) represented the e2/e4 genotype, first and fourth bands (at 94 and 58 bp levels) represented the e3/e3 genotype, first and last two bands (at 94, 66 and $58 \mathrm{bp}$ levels) represented the e3/e4 genotype, and last two bands (at 66 and 58 bp levels) represented the e4/e4 genotypes.

\section{Statistical analysis}

Predictive Analysis SoftWare (PASW) version 18 was used for data analyses. A p-value of $<0.05$ at $95 \%$ confidence interval was considered as statistically significant. Categorical data were compared by using 


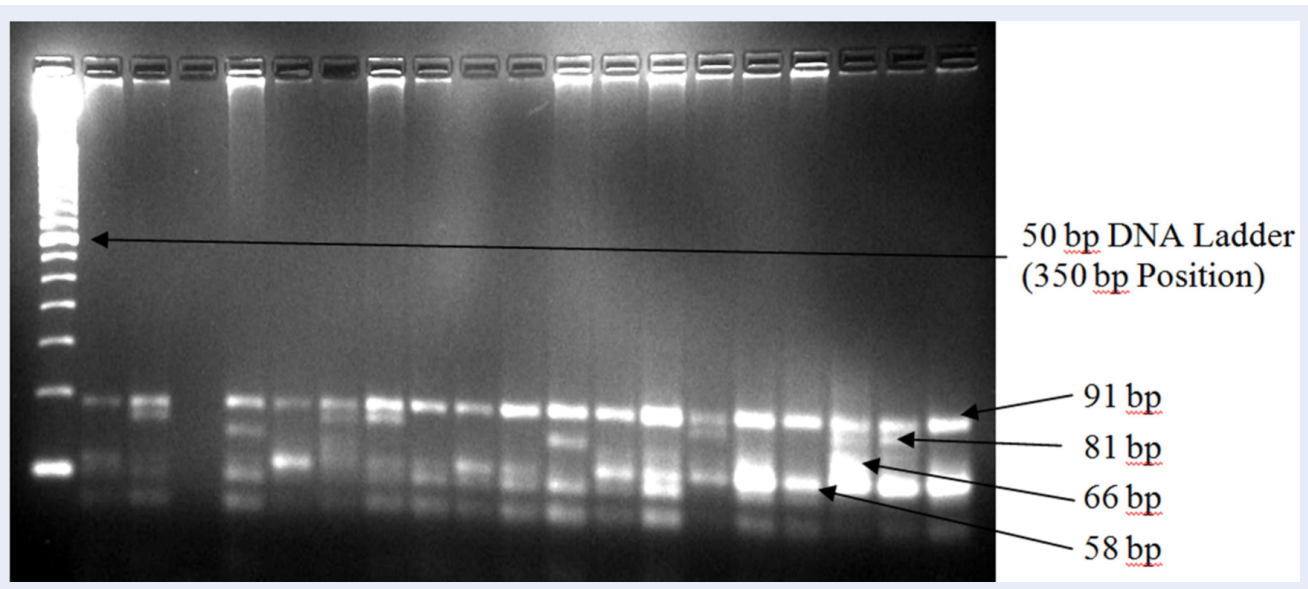

Figure 1: Different diagnostic band after Hhal Restriction Enzyme digestion.

Pearson chi-squared $\left(\chi^{2}\right)$ test. Comparisons between categorical and numerical data were performed using one-way analysis of variance (ANOVA) followed by Tukey's post-hoc test. Distribution of the APOE gene polymorphism was tested for the Hardy-Weinberg equilibrium. The data were presented as mean \pm standard deviation (SD).

\section{RESULTS}

\section{Demographic characteristics of the study subjects showed no significant difference}

The demographic characteristics of the study subjects are shown in Table 1. Distributions based on the ethnicity, gender, mean age and different age groups were similar between the groups ( $\mathrm{p}$-values were 1.00, 0.23, 0.35 and 0.33 , respectively). Mean systolic and diastolic blood pressures (BP) were not significantly different between the groups ( $p$-values were 0.49 for systolic and 0.41 for diastolic BP).

\section{Distribution of the Apolipoprotein E gene polymorphism}

Distribution based on the APOE genotypes and alleles were shown in Table 2. Five out of six (except e2/e2 genotype) APOE genotypes were identified in the study samples. The highest prevalence was observed for the e3/e3 genotypes in both cases and control groups, followed by e3/e4, e2/e4, e2/e3, and e4/e4 genotypes. Though there was no significant difference in the prevalence of genotypes, percentage of e3/e3 genotype was slightly lower, while e2/e3 and e4/e4 genotypes were marginally higher among the subjects with T2DM compared to the subjects without T2DM. e3 allele was observed with the highest percentage followed by e 4 allele and e 2 allele in both groups. Similar to genotypes, no significant difference in the frequencies of alleles were observed. However, the percentage of both e 2 and e4 alleles were slightly higher and e3 allele was slightly lower in the diabetes group compared to the control group. Similar results were also observed when the samples were subdivided based on their ethnicity. However, the changes were too small to reach the level of statistical significance using the Pearson chi-squared test ( $\mathrm{p}=0.58$ for $A P O E$ genotypes and alleles, 0.91 for the Malay study subjects and 0.46 for the Chinese study subjects). When the samples were tested for the Hardy-Weinberg equilibrium, samples within the diabetes group, both the Malays and Chinese, followed equilibrium. But the distribution in non-diabetes group was found to be significantly $(\mathrm{p}=0.0007)$ deviated from equilibrium; more specifically within the Malay subjects $(\mathrm{p}=0.0002)$. Within the non-diabetes group, allelic distribution was significantly different between the Malay and Chinese subjects $(p=0.03)$. The e 3 allele was less prevalent among Malay subjects (56.2\%) compared to Chinese subjects (79.6\%) in the control group. Meanwhile, the e4 allele was almost double and $\mathrm{e} 2$ allele was four times more prevalent in the Malay control subjects compared to Chinese controls.

Test for the association between APOE and T2DM also did not show any significant difference. Odd ratio between e2 allele and others was 1.51 (95\% $\mathrm{CI}=0.615-3.706, \mathrm{p}=0.37$ ), between e3 allele and others was 0.77 (95\% $\mathrm{CI}=0.431-1.375, \mathrm{p}=0.38)$, and between e4 allele and others was $1.12(95 \% \mathrm{CI}=0.584$ 2.131, $\mathrm{p}=0.74)$. 
Table 1: Demographic characteristics of the study subjects

\begin{tabular}{lcc}
\hline & Non-diabetes & Diabetes \\
Ethnicity & & \\
Malay & $24(47.1)$ & $24(47.1)$ \\
Chinese & $27(52.9)$ & $27(52.9)$ \\
Gender & & \\
Male & $26(51)$ & $32(62.7)$ \\
Female & $25(49)$ & $19(37.3)$ \\
Age groups & & \\
$40-49$ years & $1(2.0)$ & $1(2.0)$ \\
$50-59$ years & $5(9.8)$ & $7(13.7)$ \\
$60-69$ years & $18(35.3)$ & $17(33.3)$ \\
$70-79$ years & $15(29.4)$ & $22(43.1)$ \\
$80-89$ years & $8(15.7)$ & $3(5.9)$ \\
$>90$ years & $4(7.8)$ & $1(2.0)$ \\
Mean age & $69.2(9.6)$ & $71.1(11.3)$ \\
Blood Pressure & & \\
Systolic & & $131.81(10.13)$ \\
Diastolic & $134.58(18.76)$ & $79.52(10.52)$ \\
Fasting Blood Glucose & $82.55(16.59)$ & $9.21(2.21)$ \\
\hline
\end{tabular}

Table 2: Distribution of different APOE genotypes and alleles among the study subjects

\begin{tabular}{lcc}
\hline Genotype & $\begin{array}{c}\text { Non-diabetes } \\
\text { no. }(\%)\end{array}$ & $\begin{array}{c}\text { Diabetes } \\
\text { no. }(\%)\end{array}$ \\
e2/e2 & $0(0.0)$ & $0(0.0)$ \\
e2/e3 & $2(3.9)$ & $6(11.8)$ \\
e2/e4 & $7(13.7)$ & $7(13.7)$ \\
e3/e3 & $27(52.9)$ & $22(43.1)$ \\
e3/e4 & $14(27.5)$ & $14(27.5)$ \\
e4/e4 & $1(2.0)$ & $2(3.9)$ \\
Total & $51(100)$ & $51(100)$ \\
Alleles & & $13(12.7)$ \\
e2 & $9(8.8)$ & $64(62.8)$ \\
e3 & $70(68.6)$ & $25(24.5)$ \\
e4 & $23(22.6)$ & \\
\hline
\end{tabular}


Apolipoprotein E gene polymorphism and fasting glycemic status

Means of the FBG $( \pm S D)$ in relation to different APOE alleles between the study groups are shown in Figure 2. In both the study groups, e2 allele holds the highest mean FBG values followed by $\mathrm{e} 4$ and then e3 alleles. Mean differences were found to be statistically significant between alleles in diabetes group ( $\mathrm{p}$ $=0.011)$, but not in the control group $(\mathrm{p}=0.978)$. Within the diabetes group, both the e2 and e4 alleles had significantly higher mean FBG compared to e3 allele, $\mathrm{p}=0.026$ and 0.036 , respectively.

\section{DISCUSSION}

In this study, the distribution of $A P O E$ gene polymorphism did not show any significant difference between cases and control groups. However, HardyWeinberg equilibrium test showed a significant difference in the allelic distribution between the Malay and Chinese race of non-diabetic subjects. Distribution of e2 and e4 alleles in Malay control subjects compared to Chinese controls was four and two times higher, respectively. Like Malay subjects, comparatively higher frequency of e4 allele was also observed in Indonesian populations, and certain parts of African, European and Oceania countries ${ }^{22-27}$. This finding is also consistent with two studies conducted in Singapore, where Malay aboriginal subjects were recruited ${ }^{28,29}$. On the other hand, the distribution of $A P O E$ alleles within Chinese subjects follows the worldwide $A P O E$ distribution ${ }^{30}$, including the part of China, Japan, Taiwan and Korea ${ }^{13,21,31}$. Certain European countries also demonstrated similar distribution ${ }^{26,32}$. According to Corbo and Scacchi (1999), APOE e3 allele is the most frequent among populations that have a long established agricultural economy, and e4 allele remains higher in populations where an economy of foraging still exists and food supply is, or was in the recent past, scarce and sporadically available ${ }^{30}$.

There was no significant association between $A P O E$ alleles and T2DM in this study. It is noteworthy to mention that the percentages of the e2 and e4 alleles were slightly higher among the subjects with T2DM. Meanwhile, among the subjects with T2DM, mean FBG concentration was found significantly higher in subjects with e2 and e4 alleles compared to subjects with e3 allele. Similarly, the highest mean FBG was observed within e2 allelic control subjects, followed by e4 and the e3 allelic control subjects. Although plasma apoE protein does not have any direct effects on carbohydrate metabolism, its role in the development of obesity that eventually leads to the development of metabolic syndrome and insulin resistance had already been explored ${ }^{33}$. Sima et al. reported a weak correlation between e4 allele with metabolic syndrome $^{34}$. Whereas, Helkala et al. reported that e2-allele-carrying subjects had relatively higher fasting and 2-h blood glucose than the subject carrying other phenotypes ${ }^{35}$. Duman et al. also reported similar observation in a Turkish study population with $\mathrm{T}_{2} \mathrm{DM}^{36}$.

Numerous studies have been conducted around the world regarding the relationship between the $A P O E$ gene polymorphism and diseases that are caused by or lead to dyslipidemia ${ }^{37-41}$. It was initiated by exploring the role of the e2 allele (more specifically the e2/e2 genotype) in the pathogenesis of type III hyperlipidemia that could leads to premature coronary artery disease ${ }^{37}$. Subsequent studies discovered the role of e4 allele on the pathogenesis of Alzheimer's diseases, atherosclerosis and cerebrovascular diseases as well ${ }^{38-41}$. A number of studies also tried to find out a relationship between $A P O E$ gene polymorphism with T2DM and its complications. However, most of the studies were inconclusive. Only Liu et al. and Errera et al. suggested e2 allele as a risk factor for the development of T2DM in the Chinese and Brazilian populations ${ }^{17,18}$. The e2 allele was also reported to be associated with T2DM mediated nephropathy ${ }^{19-21}$. Increased risk of retinopathy in patients with T2DM was linked to the higher e4 allele frequency ${ }^{42}$. Most recently, Anthopoulos et al. conducted a meta-analysis, where they suggested the e2 allele as a moderate risk factor for the T2DM ${ }^{43}$.

Almost all studies were conducted to prove a causal relationship between $A P O E$ gene polymorphism and the risk of T2DM faced sample scarcity. However, original research and meta-analysis that reported a causal relationship between them recruited subjects with T2DM along with its complications, such as diabetic nephropathy, diabetic retinopathy, and/or diabetes with IHD, stroke etc. ${ }^{19-21,42,43}$. Similar to other previous studies, small sample size might be a cause behind the failure to find any association between APOE gene polymorphism and T2DM in this study. The subjects included in the study were free from any other diabetes mediated complications. But this study has generated a hypothesis on the causal relationship between $A P O E$ gene polymorphism and FBG concentration among the subjects with or without the T2DM.

\section{CONCLUSIONS}

Though this study represents preliminary data, it showed that subjects carrying e2 and e4 APOE alleles have poor glycemic control. Frequencies of these 


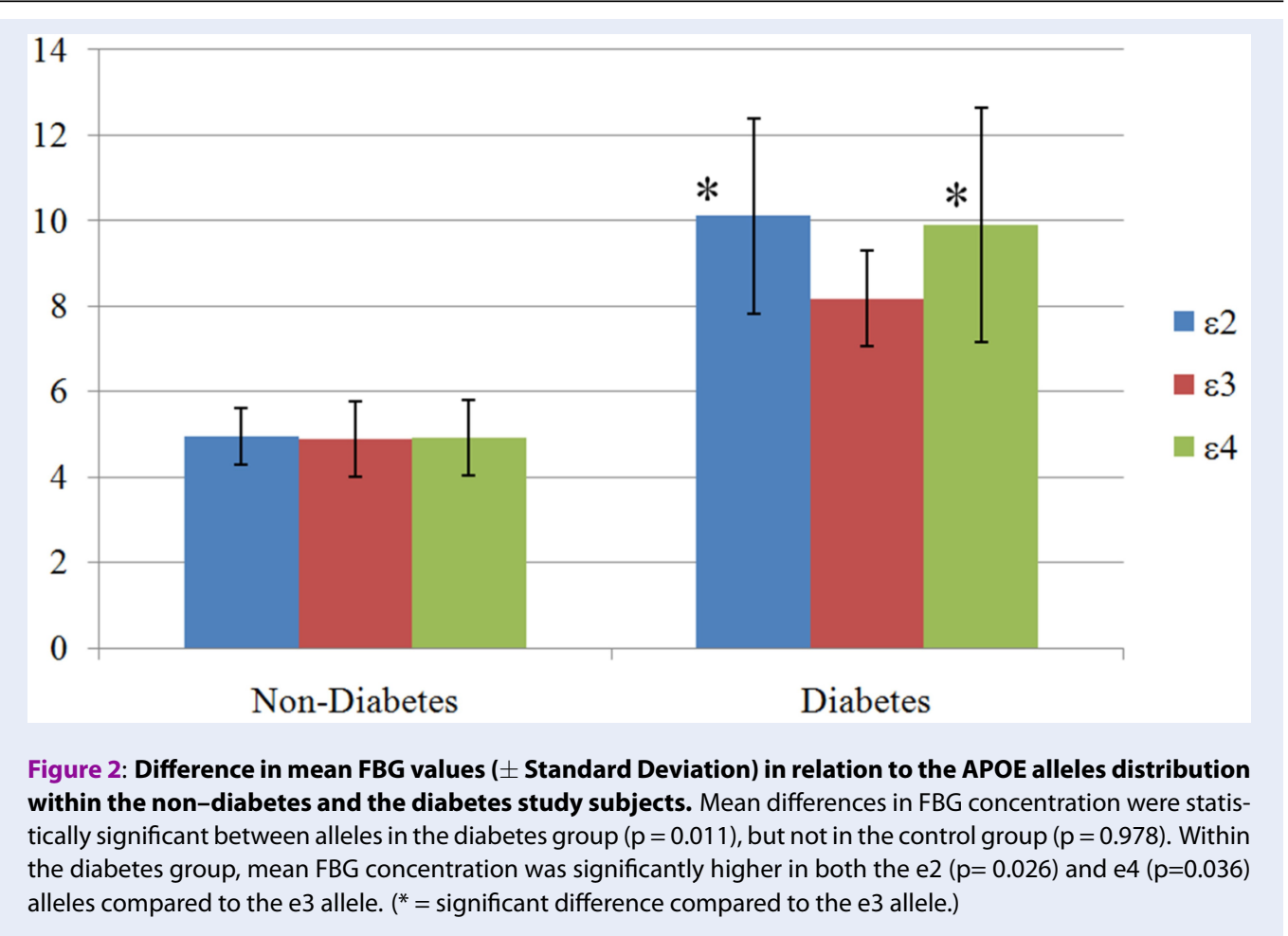

two alleles were also slightly higher among the subjects with T2DM. The e3 allelic subjects were found relatively safe in terms of the glycemic control and the occurrence of the T2DM. Further study with a larger sample size could help to improve the outcome of this research along with a proper conclusive causal relationship.

\section{ABBREVIATIONS}

ANOVA: Analysis of variance APOE: Apolipoprotein E gene apoE: Apolipoprotein E glycoprotein bp: Base pair EDTA: Ethylenediaminetetraacetic acid FBG: Fasting blood glucose

IDL: Intermediate density lipoprotein

LDL: Low-density lipoprotein

LDLr: Low-density lipoprotein receptors

PASW: Predictive Analytics Software

PCR: Polymerase chain reaction

SD: Standard deviation

T1DM: Type 1 diabetes mellitus

T2DM: Type 2 diabetes mellitus

WHO: World Health Organization

\section{COMPETING INTERESTS}

Authors declare no conflict of interests.

\section{AUTHORS' CONTRIBUTIONS}

KMHR and TBAR conceptualized and designed the work. KMHR carried out the experiment. KMHR and MSH conducted formal analysis. KMHR, MSH, $\mathrm{NH}, \mathrm{TBAR}$ and HA prepared the original draft. $\mathrm{MSH}$ and $\mathrm{NH}$ reviewed and edited the drafts. All authors approved the manuscript.

\section{FUNDING}

This study was financially supported by the IIUM University Research Grant, EDW B 11-139-0478.

\section{ACKNOWLEDGMENTS}

We extremely liked to acknowledge the supports from the Non-Communicable Disease Research Unite (NCD_RU), Kulliyyah of Medicine, International Islamic University Malaysia and the intellectual supports from the coordinator of the NCD_RU, Dr. Seikh Farid Uddin Akter.

\section{REFERENCES}

1. Global status report on noncommunicable diseases. Switzerland: World Health Organization; 2014.

2. National Health and Morbidity Survey 2015 Kuala Lumpur, Malaysia. Institute for Public Health; 2015.

3. Reddy PH. Can Diabetes Be Controlled by Lifestyle Activities? Current research in diabetes \& obesity journal. 2017; 1 (4):555568.

4. Dajani R, Li J, Wei Z, March ME, Xia Q, Khader Y, et al. Genomewide association study identifies novel type II diabetes risk loci in Jordan subpopulations. PeerJ. 2017;5:e3618. Available from: $10.7717 /$ peerj. 3618 . 
5. Franks PW, Pearson E, Florez JC. Gene-environment and genetreatment interactions in type 2 diabetes: progress, pitfalls, and prospects. Diabetes Care. 2013;36(5):1413-21. PMID: 23613601. Available from: $10.2337 / \mathrm{dc} 12-2211$.

6. Sladek R, Rocheleau G, Rung J, Dina C, Shen L, Serre D, et al. A genome-wide association study identifies novel risk loci for type 2 diabetes. Nature. 2007;445(7130):881-5. PMID: 17293876. Available from: 10.1038/nature05616.

7. Shcherbak NS. Apolipoprotein E gene polymorphism is not a strong risk factor for diabetic nephropathy and retinopathy in Type I diabetes: case-control study. BMC Med Genet. 2001;2(1):8. PMID: 11495633. Available from: 10.1186/14712350-2-8.

8. Rebeck GW, LaDu MJ, Estus S, Bu G, Weeber EJ. The generation and function of soluble apoE receptors in the CNS. Mol Neurodegener. 2006;1(1):15. PMID: 17062143. Available from: 10.1186/1750-1326-1-15.

9. Rall SC, Weisgraber KH, Mahley RW. Human apolipoprotein $\mathrm{E}$. The complete amino acid sequence. J Biol Chem. 1982;257(8):4171-8. PMID: 7068630.

10. Raffai RL, Hasty AH, Wang $Y$, Mettler SE, Sanan DA, Linton MF. Hepatocyte-derived ApoE is more effective than nonhepatocyte-derived ApoE in remnant lipoprotein clearance. J Biol Chem. 2003;278(13):11670-5. PMID: 12551940. Available from: $10.1074 / \mathrm{jbc} . \mathrm{M} 212873200$.

11. Hagberg JM, Wilund KR, Ferrell RE. APO E gene and geneenvironment effects on plasma lipoprotein-lipid levels. Physiol Genomics. 2000;4(2):101-8. PMID: 11120871. Available from: 10.1152/physiolgenomics.2000.4.2.101.

12. Moreno JA, Pérez-Jiménez F, Marín C, Gómez P, PérezMartínez $P$, Moreno $R$, et al. The effect of dietary fat on $L D L$ size is influenced by apolipoprotein $E$ genotype in healthy subjects. J Nutr. 2004;134(10):2517-22. PMID: 15465740. Available from: 10.1093/jn/134.10.2517.

13. Shin MH, Kim HN, Cui LH, Kweon SS, Park KS, Heo H, et al. The effect of apolipoprotein $\mathrm{E}$ polymorphism on lipid levels in Korean adults. J Korean Med Sci. 2005;20(3):361-6. PMID: 15953853. Available from: 10.3346/jkms.2005.20.3.361.

14. Lin QY, Du JP, Zhang MY, Yao YG, Li L, Cheng NS, et al. Effect of apolipoprotein $\mathrm{E}$ gene $\mathrm{H}$ ha I restricting fragment length polymorphism on serum lipids in cholecystolithiasis. World J Gastroenterol. 1999;5(3):228-30. PMID: 11819436. Available from: 10.3748/wjg.v5.i3.228.

15. Siest G, Pillot T, Régis-Bailly A, Leininger-Muller B, Steinmetz J, Galteau MM, et al. Apolipoprotein E: an important gene and protein to follow in laboratory medicine. Clin Chem. 1995;41(8 Pt 1):1068-86. PMID: 7628082.

16. Ingelsson $M$, Shin $Y$, Irizarry MC, Hyman BT, Lilius L, Forsell $C$, et al. Genotyping of apolipoprotein E: comparative evaluation of different protocols. Curr Protoc Hum Genet. 2003;Chapter 9:Unit9.14.

17. Liu L, Xiang K, Zheng T, Zhang R, Li M, Li J. Co-inheritance of specific genotypes of HSPG and ApoE gene increases risk of type 2 diabetic nephropathy. Mol Cell Biochem. 2003;254(12):353-8. PMID: 14674716. Available from: 10.1023/A: 1027364121738 .

18. Errera Fl, Silva ME, Yeh E, Maranduba CM, Folco B, Takahashi W, et al. Effect of polymorphisms of the MTHFR and APOE genes on susceptibility to diabetes and severity of diabetic retinopathy in Brazilian patients. Braz J Med Biol Res. 2006;39(7):883-8. PMID: 16862278. Available from: 10.1590/ S0100-879X2006000700005.

19. Eto M, Horita K, Morikawa A, Nakata H, Okada M, Saito M, et al Increased frequency of apolipoprotein $\varepsilon 2$ allele in non-insulin dependent diabetic (NIDDM) patients with nephropathy. Clin Genet. 1995;48(6):288-92. PMID: 8835322. Available from: 10.1111/j.1399-0004.1995.tb04111.x.

20. Hsieh MC, Lin SR, Yang YC, Chen HC, Lin JN, Shin SJ. Higher frequency of apolipoprotein E2 allele in type 2 diabetic patients with nephropathy in Taiwan. J Nephrol. 2002;15(4):368-73. PMID: 12243365.
21. Horita K, Eto M, Makino I. Apolipoprotein E2, renal failure and lipid abnormalities in non-insulin-dependent diabetes mellitus. Atherosclerosis. 1994;107(2):203-11. PMID: 7980694. Available from: 10.1016/0021-9150(94)90021-3.

22. Hastuti P, Sofro AS, Asdie AH, Sadewa AH. Genetic Variation of Apolipoprotein E (ApoE) in Surabaya, Palu and Alor Populations of Indonesia. Indones J Biotechnol. 2011;16(2):118-25. Available from: 10.22146/ijbiotech.16371.

23. Zekraoui L, Lagarde JP, Raisonnier A, Gérard N, Aouizérate A, Lucotte $G$. High frequency of the apolipoprotein $E^{*} 4$ allele in African pygmies and most of the African populations in subSaharan Africa. Hum Biol. 1997;69(4):575-81. PMID: 9198315.

24. Chen $\mathrm{CH}$, Mizuno $\mathrm{T}$, Elston $\mathrm{R}$, Kariuki MM, Hall $\mathrm{K}$, Unverzagt $F$, et al. A comparative study to screen dementia and APOE genotypes in an ageing East African population. Neurobiol Aging. 2010;31(5):732-40. PMID: 18703255. Available from: 10.1016/j.neurobiolaging.2008.06.014.

25. Masemola ML, Alberts M, Urdal P. Apolipoprotein E genotypes and their relation to lipid levels in a rural South African population 1. Scand J Public Health. 2007;35(69_suppl):60-5.

26. Gerdes LU, Klausen IC, Sihm I, Faergeman O, Vogler G. Apolipoprotein E polymorphism in a Danish population compared to findings in 45 other study populations around the world. Genet Epidemiol. 1992;9(3):155-67. PMID: 1381696. Available from: 10.1002/gepi.1370090302.

27. Singh PP, Singh M, Mastana SS. APOE distribution in world populations with new data from India and the UK. Ann Hum Biol. 2006;33(3):279-308. PMID: 17092867. Available from: 10.1080/03014460600594513.

28. Gajra B, Candlish JK, Saha N, Mak JW, Tay JS. Effect of apolipoprotein $\mathrm{E}$ variants on plasma lipids and apolipoproteins in the Orang Asli ('aborigines') of Malaysia. Hum Hered. 1994;44(4):209-13. PMID: 8056432. Available from: 10.1159/ 000154219.

29. Tan CE, Tai ES, Tan CS, Chia KS, Lee J, Chew SK, et al. APOE polymorphism and lipid profile in three ethnic groups in the Singapore population. Atherosclerosis. 2003;170(2):253-60. PMID: 14612205. Available from: 10.1016/S0021-9150(03)00232-6.

30. Corbo RM, Scacchi R, Apolipoprotein E. Apolipoprotein E (APOE) allele distribution in the world. Is APOE*4 a 'thrifty' allele? Ann Hum Genet. 1999;63(Pt 4):301-10. PMID: 10738542. Available from: 10.1046/j.1469-1809.1999.6340301.x.

31. Lin SK, Kao JT, Tsai SM, Tsai LY, Lin MN, Lai CJ, et al. Association of apolipoprotein $\mathrm{E}$ genotypes with serum lipid profiles in a healthy population of Taiwan. Ann Clin Lab Sci. 2004;34(4):443-8. PMID: 15648787.

32. Corbo RM, Scacchi R, Mureddu L, Mulas G, Alfano G. Apolipoprotein E polymorphism in Italy investigated in native plasma by a simple polyacrylamide gel isoelectric focusing technique. Comparison with frequency data of other European populations. Ann Hum Genet. 1995;59(2):197-209. PMID: 7625766. Available from: 10.1111/j.1469-1809.1995. tb00741.x.

33. Rutkowski JM, Davis KE, Scherer PE. Mechanisms of obesity and related pathologies: the macro- and microcirculation of adipose tissue. FEBS J. 2009;276(20):5738-46. PMID: 19754873. Available from: $10.1111 /$ j.1742-4658.2009.07303.x.

34. Sima A, lordan A, Stancu C. Apolipoprotein E polymorphismrisk factor for metabolic syndrome. Clin Chem Lab Med. 2007;45(9):1149-53. PMID: 17848120. Available from: 10. 1515/CCLM.2007.258.

35. Helkala EL, Lakka T, Vanhanen M, Tuomainen TP, Ehnholm C, Kaplan GA, et al. Associations between apolipoprotein E phenotype, glucose metabolism and cognitive function in men. An explorative study in a population sample. Diabet Med. 2001;18(12):991-7. PMID: 11903399. Available from: 10.1046/j.0742-3071.2001.00588.x.

36. Duman BS, Oztürk M, Yilmazer S, Hatemi H. Apolipoprotein E polymorphism in Turkish subjects with Type 2 diabetes mellitus: allele frequency and relation to serum lipid concentrations. Diabetes Nutr Metab. 2004;17(5):267-74. PMID: 16295048. 
37. Utermann G, Hees M, Steinmetz A. Polymorphism of apolipoprotein $\mathrm{E}$ and occurrence of dysbetalipoproteinaemia in man. Nature. 1977;269(5629):604-7. PMID: 199847. Available from: $10.1038 / 269604 \mathrm{a} 0$.

38. Hill JM, Bhattacharjee PS, Neumann DM. Apolipoprotein E alleles can contribute to the pathogenesis of numerous clinical conditions including HSV-1 corneal disease. Exp Eye Res. 2007;84(5):801-11. PMID: 17007837. Available from: 10.1016/ j.exer.2006.08.001.

39. Kim IJ, Hong BK, Lee BK, Kwon HM, Kim D, Choi EY, et al. Apolipoprotein E polymorphism in non-diabetic patients with acute coronary syndrome. Yonsei Med J. 1999;40(4):377-82. PMID: 10487142. Available from: 10.3349/ymj.1999.40.4.377.

40. Wilson PW, D'Agostino RB, Parise H, Sullivan L, Meigs JB. Metabolic syndrome as a precursor of cardiovascular disease and type 2 diabetes mellitus. Circulation. 2005;112(20):3066-72. PMID: 16275870. Available from:
10.1161/CIRCULATIONAHA.105.539528.

41. McCarron MO, Nicoll JA, Stewart J, Ironside JW, Mann DM Love $\mathrm{S}$, et al. The apolipoprotein $\mathrm{E}$ epsilon2 allele and the pathological features in cerebral amyloid angiopathy-related hemorrhage. J Neuropathol Exp Neurol. 1999;58(7):7118. PMID: 10411341. Available from: 10.1097/00005072199907000-00005.

42. Santos A, Salguero ML, Gurrola C, Muñoz F, Roig-Melo E, Panduro $A$. The epsilon4 allele of apolipoprotein $E$ gene is a potential risk factor for the severity of macular edema in type 2 diabetic Mexican patients. Ophthalmic Genet. 2002;23(1):139. PMID: 11910554. Available from: 10.1076/opge.23.1.13.2203.

43. Anthopoulos PG, Hamodrakas SJ, Bagos PG. Apolipoprotein E polymorphisms and type 2 diabetes: a meta-analysis of 30 studies including 5423 cases and 8197 controls. Mol Genet Metab. 2010;100(3):283-91. PMID: 20381392. Available from: 10.1016/j.ymgme.2010.03.008. 